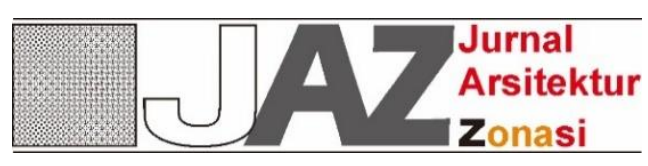

http://ejournal.upi.edu/index.php/jaz - e-mail: jurnal.zonasi@gmail.com dan jurnal_zonasi@upi.edu doi.org/10.17509/jaz.v3i2.25061

\title{
EMBODIED ENERGY PADA DINDING BAMBU ANYAMAN DAN PLESTER
}

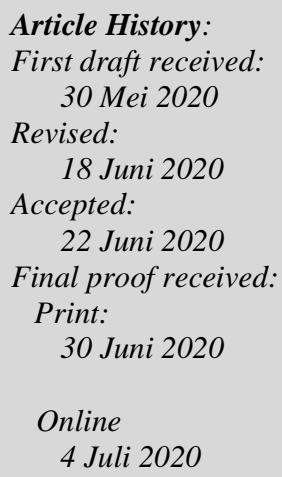

Jurnal Arsitektur ZONASI is indexed and listed in several databases:

SINTA 4 (Arjuna)

GARUDA (Garda Rujukan Digital)

Google Scholar

Dimensions

oneSearch

BASE

Member:

Crossref

RJI

APTARI

FJA (Forum Jurna Arsitektur) IAI AJPKM

\author{
Aldissain Jurizat $^{1}$ \\ Try Ramadhan ${ }^{2}$ \\ 1,2 Departemen Pendidikan Teknik Arsitektur, Universitas Pendidikan Indonesia, Indonesia \\ Jalan Dr. Setiabudhi No. 207, Bandung \\ Email: aldissain@upi.edu \\ tryramadhan@upi.edu
}

\begin{abstract}
Buildings consume high energy and cause an increase in CO2 gas emissions to the environment. This energy consumption is known as embodied energy where energy is used in the production and maintenance processes of buildings. In buildings, the largest consumption of embodied energy is contained in the walls. Among the various materials and construction of building walls, the trend of the plaster bamboo wall has been significantly increased because it has several advantages for the environment. This research was conducted to measure the embodied energy contained in bamboo wall construction located in Kampung Buyut Cipageran, Cimahi City. This research method uses Inventory Carbon and Energy (ICE) data from the University of Bath and Indonesian National Standard as the basics data for the calculation. The analysis has been conducted by calculating the basics data and the design drawings. The result showed that the embodied energy in the bamboo walls had a value of $230.61 \mathrm{MJ} / \mathrm{m}^{2}$. This result is lower than the known standard for brick wall with $440 \mathrm{MJ} / \mathrm{m}^{2}$. The bamboo wall is proved to be more efficient in energy use than conventional wall with brick as the main construction.
\end{abstract}

Keywords: bamboo wall; embodied energy;

Abstrak: Bangunan mengkonsumsi energi yang cukup tinggi dan mengakibatkan peningkatan emisi gas $\mathrm{CO} 2$ ke lingkungan. Penggunaan energi ini diketahui sebagai embodied energy dimana energi digunakan dalam proses produksi dan perawatan bangunan. Dalam suatu bangunan, penggunaan embodied energy terbesar terletak pada dinding. Dari berbagai material dan konstruksi pembentuk dinding bangunan, dinding bambu plester menjadi tren terbaru karena memiliki beberapa keunggulan dalam keramahan terhadap lingkungan. Penelitian ini dilakukan untuk mengukur embodied energy yang terdapat pada komponen dinding bambu di salah satu bangunan Kampung Buyut Cipageran, Kota Cimahi. Metode pengukuran menggunakan data Inventory Carbon and Energy (ICE) dari University of Bath dan petunjuk analisis pekerjaan konstruksi dari SNI. Hasil analisis menunjukkan bahwa embodied energy pada dinding bambu plester memiliki nilai $230,61 \mathrm{MJ} / \mathrm{m}^{2}$. Jika dibandingkan dengan dinding bata plester konvensional yang memiliki standar $440 \mathrm{MJ} / \mathrm{m}^{2}$, dinding bambu plester lebih efisien dalam penggunaan energi dalam siklus hidupnya.

Kata Kunci: dinding bambu; embodied energy;

\section{Pendahuluan}

Konsumsi energi di dunia merupakan salah satu isu yang menjadi prioritas masyarakat dunia saat ini. Sektor bangunan mengkonsumsi kurang lebih 40\% dari total energi global (Waqas dan Ud Din, 2013). Dalam praktiknya, energi memang selalu menyertai setiap aktivitas pembangunan. Dimulai sejak material diekstraksi dari pertambangan hingga bangunan dihancurkan, semuanya tentu mengkonsumsi energi. Energi yang terkandung dalam aktivitas pembangunan baik langsung maupun tidak langsung tersebut biasanya disebut sebagai embodied energy (EE) (Wahyuni \& Larasati, 2017). Menurut Treloar (1998), embodied energy adalah 
seluruh energi yang melekat atau dikonsumsi dalam semua tahapan kegiatan yang diperlukan untuk menunjang sebuah proses pembuatan sebuah benda atau produk. Berbagai dampak lingkungan yang diakibatkan oleh konsumsi energi seperti emisi karbon $\left(\mathrm{CO}_{2}\right)$ secara tidak langsung menjadikan embodied energy sebagai isu yang mulai diperhatikan oleh dunia saat ini. Beberapa dampak tersebut adalah pemanasan global dan perubahan iklim.

Embodied energy dapat dilihat melalui aspek proses yang terdiri dari dua jenis, yaitu: embodied energy dalam siklus energi bangunan dan embodied energy dalam siklus hidup material. Embodied energy dalam siklus energi bangunan menurut Ramesh dkk. (2010) digambarkan sebagai total energi yang dibutuhkan dan digunakan dari awal pembuatan material, instalasi material, dan renovasi material pada bangunan hingga penghancuran. Sedangkan embodied energy dalam siklus hidup material lebih berkaitan dengan energi yang dibutuhkan untuk memproduksi sebuah material. Energi tersebut meliputi energi penggunaan bahan bakar pada peralatan yang digunakan untuk pengumpulan, penggalian, dan penambangan material mentah, dan energi pada alat transportasi yang digunakan untuk memindahkan material mentah menuju pabrik untuk diolah lebih lanjut (Dixit dkk, 2010).

Kedua aspek tersebut merupakan satu gabungan embodied energy yang saling berhubungan dalam siklus keberadaan suatu bangunan. Penggunaan energi dapat dibagi berdasarkan fase siklus hidup bangunan yaitu fase ekstraksi sumber material, produksi pabrik, konstruksi dan fase pemasangan, penggunaan dan perawatan, penghancuran, dan fase daur ulang/penggunaan kembali hingga pembuangan (Zhang \& Wang, 2016). Pembagian penggunaan energi pada siklus hidup bangunan dijelaskan dalam Gambar 1.

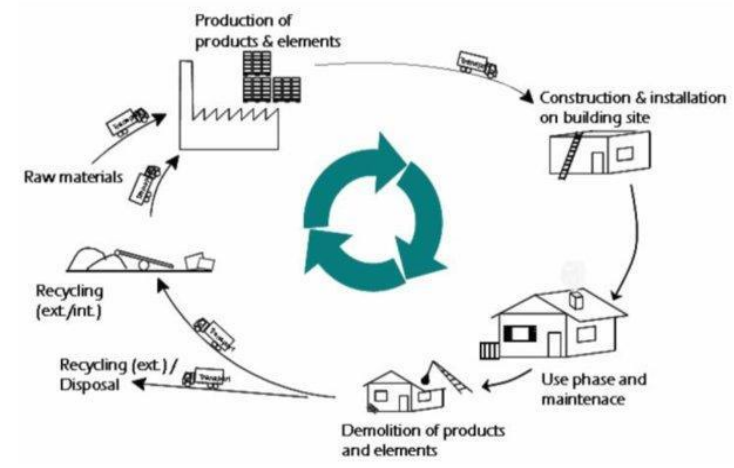

Gambar 1. Pembagian penggunaan energi fase siklus hidup bangunan

Sumber: Sentzas, dkk., 2017

Embodied energy pada bangunan berhubungan dengan siklus hidup bangunan yang menggunakan energi pada awal pembangunan (energi yang digunakan untuk ekstraksi, transportasi, dan pemasangan material), energi yang digunakan untuk perawatan dan perbaikan, hingga energi yang dikonsumsi untuk penghancuran bangunan (Manish K. Dixit, 2017). Semakin besar penggunaan embodied energy-maka semakin besar gambaran penggunaan energi keseluruhan bangunan. Embodied energy inilah yang kemudian dapat menjadi indikator terukur dalam menghitung besaran nilai energi yang dikonsumsi bangunan. Besaran nilai embodied energy yang bersifat kuantitatif dapat lebih mudah dipahami oleh semua pihak sebagai acuan, perbandingan atau penilaian. Nilai tersebut diharapkan dapat memberikan pertimbangan dalam upaya meminimalisir penggunaan energi yang sudah sangat besar oleh sektor bangunan (Wahyuni \& Larasati, 2017 dan Anonym, 2014).

Beberapa penelitian sebelumnya terkait energi ini sudah pernah dilakukan di Indonesia, salah satunya oleh Surahman, Kubota, \& Higashi (2015) yang menyajikan secara keseluruhan energi bangunan pada objek rumah di beberapa kota besar di Indonesia. Penelitian Larasati, dkk, (2017) juga pernah melakukan identifikasi embodied energy pada beberapa tipe hunian di Indonesia sebagai upaya mitigasi bencana dengan menggunakan data Inventory Carbon and Energy (ICE) dari University of Bath. Kedua penelitian tersebut mengakses konsumsi energi hunian-hunian yang menggunakan material yang sering digunakan di Indonesia.

Salah satu elemen bangunan yang mengkonsumsi energi paling besar adalah dinding. Dalam penelitian yang dilakukan oleh Hanifah dkk., (2019), elemen dinding merupakan faktor paling signifikan yang berkontribusi terhadap nilai EE pekerjaan arsitektur pada bangunan. Pada penelitian rumah tinggal sederhana di Indonesia, embodied energy dari konstruksi dinding bata dan batako yang digunakan berpengaruh signifikan terhadap nilai embodied energy total bangunan (Utama dan Gheewala, 2008 dalam Pratiwi, 2011). Hal ini dapat disebabkan akibat besarnya proporsi material bangunan yang digunakan untuk membangun dinding sebagai selubung bangunan. Maka dari itu, sudah seharusnya menemukan alternatif lain penggunaan material yang lebih rendah energi untuk digunakan sebagai elemen dinding. 
Jenis material yang nilai EE-nya cukup besar adalah baja, besi serta alumunium karena berkaitan dengan proses pengolahan yang mengkonsumsi banyak energi. Oleh karena itu penggunaan energi perlu dibatasi dengan menggunakan material yang memiliki nilai EE-nya rendah, salah satunya adalah kayu dan bambu. Material yang langsung berasal dari alam ini memiliki karakteristik yang tepat dalam mengurangi konsumsi energi dalam bangunan. Material ini juga tidak banyak mengalami proses pengolahan sehingga tidak banyak energi yang dikeluarkan pada fase tersebut.

Bambu merupakan salah satu alternatif material bangunan yang dipercaya dapat menjawab isu lingkungan, apalagi di daerah yang banyak ditumbuhi seperti Indonesia. Bambu sebagai material ekologis seharusnya dapat dimanfaatkan lebih masif terlebih jika dapat dimodernisasi. Salah satunya seperti dinding bambu plester karena memiliki potensi yang dapat dikembangkan secara prefabrikasi (Suriani, 2017). Penelitian yang dilakukan oleh Marzuki (2019) telah menganalisis perbandingan antara penggunaan material bata dan material bambu plester dalam hal efisiensi biaya dan mengidentifikasi adanya penurunan harga dari penggunaan dinding bambu plester sebesar $31,17 \%$. Pada embodied energy, besarnya biaya yang dikeluarkan terkadang dapat berhubungan dengan energi yang dikonsumsi. Seperti dijelaskan sebelumnya kayu dan bambu merupakan material yang memiliki nilai intensitas energi yang cenderung rendah jika dibandingkan dengan bata, precast dan batako (Nairobi, 1991). Oleh karena itu, penelitian ini akan mencoba mengukur besaran nilai embodied energy pada elemen dinding bangunan yang menggunakan material bambu plester. Tujuan dari penelitian ini adalah menemukan alternatif material dinding bangunan yang memiliki potensi dalam menurunkan konsumsi energi pada bangunan.

Adapun embodied energy yang dihitung adalah nilai awal dari komponen material dinding dan embodied energy untuk perawatan komponen dinding. Embodied energy pada fase penghancuran tidak dihitung karena pengaruhnya dianggap relatif kecil, kurang lebih sebesar 1-3\% dari siklus energi bangunan (Ampofo-Anti, 2010). Nilai embodied energy awal akan didapatkan dari data inventaris embodied energy ICE (Inventory of Carbon and Energy) yang dipublikasikan oleh oleh University of Bath, Sustainable Energy Research Team (Geoff Hammond \& Jones, 2008), yang merupakan database koefisien embodied energy dan emisi karbon dari material yang diakui pada beberapa penelitian embodied energy.

Pada penelitian ini dilakukan sampel terhadap salah satu bangunan di kawasan wisata Kampung Buyut Cipageran yang terletak di Kota Cimahi. Kampung ini merupakan sebuah kawasan wisata yang dirancang oleh Ir. Pon S. Purajatnika, IAI mewakili perusahaan PT. Awi Agraprana Bestari.

\section{Metode Penelitian}

Berdasarkan Dixit (2019), embodied energy dapat dikategorikan menjadi dua bentuk atau tahapan, yaitu embodied energy yang terkandung secara langsung dan yang tidak langsung. Embodied energy langsung merupakan energi yang digunakan ketika pelaksanaan konstruksi berlangsung, biasanya berhubungan dengan pemasangan material dan komponen bangunan, kegiatan prefabrikasi, transportasi di sekitar site, hingga kegiatan administrasi selama proses konstruksi. Embodied energy tidak langsung lebih berhubungan dengan energi yang digunakan saat proses produksi dari material bangunan, energi untuk perbaikan, penggantian dan penghancuran material.

Embodied energy tidak langsung dapat dibagi tiga menjadi embodied energy awal (initial), berulang (recurrent) dan penghancuran (demolition) (Ibn-Mohammed, dkk., 2013). Embodied energy awal merupakan jumlah kebutuhan energi yang digunakan untuk produksi, penyediaan material mentah, proses produksi pabrik, dan pengiriman produk untuk pembangunan suatu bangunan. Embodied energy berulang merupakan energi yang digunakan dari proses perawatan dan penggantian material bangunan selama usia pakai hidupnya. Embodied energy penghancuran terkait dengan proses penghancuran bangunan dan pembuangan material bangunan yang tidak digunakan dari site.

Penelitian ini hanya akan mengukur embodied energy secara tidak langsung karena lingkup penelitian menggunakan objek aplikasi konstruksi pada satu bangunan. Embodied energy untuk demolish tidak digunakan karena memiliki pengaruh yang kecil dibandingkan tahapan yang lain. Telah juga diuraikan bahwa konsumsi energi pada tahap penghancuran bangunan dengan fungsi kantor tiga lantai terhitung sebesar 1-3\% dari total energi bangunan (Ampofo-Anti, 2010).

Penelitian ini bersifat kuantitatif karena melakukan perhitungan terukur dari objek yang diteliti. Analisis data akan mengkalkulasi jumlah dari embodied energy awal total (EEAT), embodied energy berulang atau perawatan total (EEPT) dan embodied energy total (EET). Data primer menggunakan dokumen studi kasus antara lain gambar bangunan, bill of quantity, dan rencana kerja dan syarat. Sedangkan data sekunder yang digunakan antara lain data inventaris energi dari ICE (Hammond \& Jones, 2008) dan analisis pekerjaan konstruksi dari SNI. Setelah didapatkan nilai EET, maka interpretasi dilakukan untuk menjelaskan data 
tersebut, baik secara terbatas maupun lebih luas dengan membandingkan dengan temuan penelitian-penelitian sebelumnya.

\subsection{Objek Penelitian}

Penelitian ini dilakukan dengan menghitung embodied energy pada salah satu bangunan di kawasan wisata Kampung Buyut Cipageran yang berlokasi di Jalan Kolonel Masturi, Kota Cimahi, Provinsi Jawa Barat. Proyek ini dirancang dan dibangun oleh PT. Awi Agraprana Bestari di tahun 2016. Kawasan ini ditujukan sebagai tempat wisata dan rekreasi dengan konsep arsitektur tradisional Sunda.

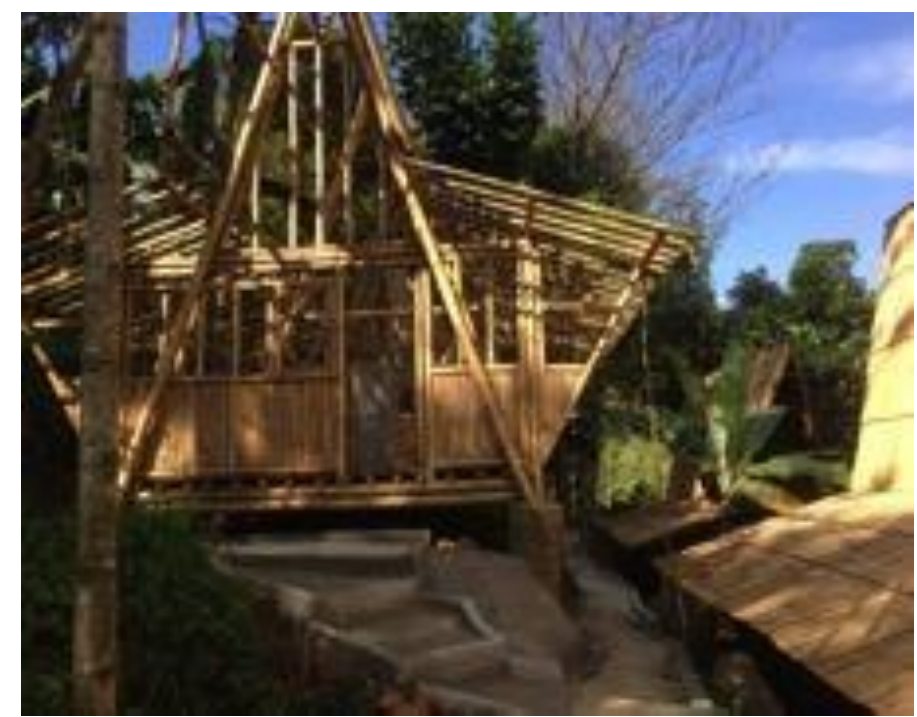

Gambar 2. Bangunan fungsi wisata yang menjadi sampel penelitian

Sumber: Ferdelina, 2016

Kawasan ini dinamakan Kampung Buyut Cipageran karena menganut budaya dan konsep masyarakat Sunda. Tujuan dari kawasan ini memang diperuntukkan untuk masyarakat umum dengan berlandaskan prinsip kearifan lokal. Harapan dari pemilik lokasi ini adalah menjaga dan melestarikan alam, seni dan budaya dari masyarakat setempat.


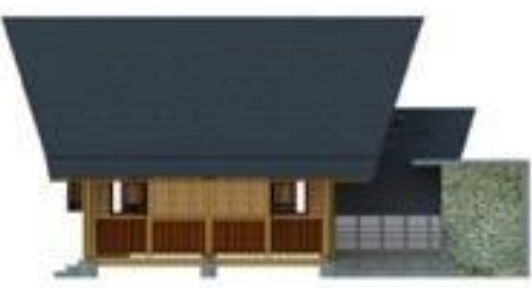

Trupax saver, katew

Gambar 3. Layout dan tampak bangunan

Sumber: PT. Awi Agraprana Bestari dalam Ferdelina, 2016

Bangunan yang menjadi objek penelitian adalah bangunan dengan fungsi resort atau wisata (lihat Gambar 2). Bangunan ini memiliki luas $16 \mathrm{~m}^{2}$ dengan bambu dan kayu menjadi komponen bahan bangunan utamanya. Konstruksi dinding pada bangunan ini terdiri dari dinding bambu dan dinding bambu dengan plester. Bangunan yang menjadi sampel penelitian memiliki satu ruang utama, selasar, toilet dan teras. Bangunan utama dan toilet terpisah oleh selasar (lihat Gambar 4). 



Gambar 4. Material kayu dan bambu sebagai komponen utama bangunan (kiri) dan proses konstruksi bangunan (kanan).

Sumber: PT. Awi Agraprana Bestari dalam Ferdelina, 2016

Material bambu dan kayu menjadi komponen utama material bangunan. Bambu yang digunakan merupakan jenis bambu tali dan bambu petung. Bambu tali memiliki ruas kurang lebih $65 \mathrm{~cm}$ dengan diameter 6-8 $\mathrm{cm}$ dan biasa tumbuh hingga 6 sampai 13 meter panjang. Usia panen ideal untuk bambu ini adalah 3-5 tahun. Bambu ini digunakan sebagai struktur penunjang dan pembentuk anyaman bambu (Gambar 4, kiri). Struktur utama bangunan menggunakan bambu jenis betung yang dikenal lebih kuat dibandingkan jenis bambu lainnya. Ukuran dari bambu ini cukup besar dengan diameter kurang lebih 10-15 cm dengan jarak ruas yang pendek serta bisa tumbuh hingga 10-20 meter, lihat Gambar 4 (kanan).


Gambar 5. Anyaman dinding yang dilapisi plester (kiri), Sambungan miring (tengah), dan sambungan T (kanan)

Sumber: PT. Awi Agraprana Bestari dalam Ferdelina, 2016

Dinding tali digunakan untuk membentuk anyaman bambu sebagai komponen utama pembentuk dinding pada bangunan. Anyaman dibuat berdasarkan kebutuhan luas permukaan dinding yang dibutuhkan. Prosesnya dilakukan langsung di lokasi pembangunan dengan perhitungan ukuran dan kondisi bambu, lihat Gambar 5 (kiri). Sistem sambungan yang digunakan adalah sambungan jenis $\mathrm{T}$ dan sambungan miring. Jenis kedua sambungan ini merupakan jenis sambungan yang paling banyak digunakan dalam konstruksi. Jenis sambungan tersebut diaplikasikan sebagai konstruksi atap dan dinding. Sambungan ini direkatkan oleh mur baut dengan cara dibor, lihat Gambar 5 (tengah dan kanan).

\subsection{Metode Perhitungan Embodied Energy Awal}

Menurut Ampofo-Anti (2010), embodied energy awal bangunan diantaranya dipengaruhi oleh produksi material, transportasi material dan metode konstruksi. Berdasarkan nilai besar energi yang diperlukan untuk memproduksi material, material bangunan dapat dikelompokkan menjadi tiga kategori: tinggi, sedang, dan rendah. Material dengan kategori tinggi menggunakan energi lebih dari $5 \mathrm{GJ} / \mathrm{ton}$. Material dengan kategori sedang menggunakan energi sebesar 0.5-5 GJ/ton. Material dengan kategori rendah menggunakan energi berkisar $0.5 \mathrm{GJ} /$ ton, lihat Tabel 1 .

Tabel 1. Pengkategorian material berdasarkan energi yang dibutuhkan dalam pembuatannya

\begin{tabular}{|l|c|}
\hline \multicolumn{1}{|c|}{ Material } & Kebutuhan energi primer (GJ/ton) \\
\hline \multicolumn{2}{|c|}{ Energi sangat tinggi } \\
\hline Alumunium & $200-250$ \\
\hline Plastik & $50-100$ \\
\hline Copper & $100+$ \\
\hline Stainless steel & $100+$ \\
\hline
\end{tabular}




\begin{tabular}{|c|c|}
\hline Material & Kebutuhan energi primer (GJ/ton) \\
\hline \multicolumn{2}{|c|}{ Energi Tinggi } \\
\hline Baja & $30-60$ \\
\hline Zinc & $25+$ \\
\hline Kaca & $12-25$ \\
\hline Semen & $5-8$ \\
\hline Plasterboard & $8-10$ \\
\hline \multicolumn{2}{|c|}{ Energi Sedang } \\
\hline Kapur & $3-5$ \\
\hline Bata dan keramik & $2-7$ \\
\hline Gypsum plaster & $1-4$ \\
\hline Beton (di tempat) & $0.8-1.5$ \\
\hline Beton block & $0.8-3.5$ \\
\hline Beton precast & $1.5-8$ \\
\hline Batako & $0.8-1.2$ \\
\hline Kayu & $0.1-5$ \\
\hline \multicolumn{2}{|c|}{ Energi Rendah } \\
\hline Pasir, agregat & $<0.5$ \\
\hline Flyash, RHA, volcanic ash & $<0.5$ \\
\hline Tanah & $<0.5$ \\
\hline
\end{tabular}

Sumber: Diadopsi dari Nairobi (1991)

Nilai-nilai koefisien embodied energy dari jenis-jenis material bangunan tersebut sudah banyak dipublikasikan beberapa negara. Hal ini juga berkaitan sudah berjalannya ISO 14040 hingga 14044 yang berkaitan dengan Life Cycle Assessment suatu produk industri di negara-negara tersebut, terlepas dengan berbagai macam metode yang dapat digunakan beserta batasan asumsinya. Meskipun begitu dengan adanya nilai koefisien tersebut, maka dapat terbentuk data inventaris yang lengkap terkait material-material yang ada.

Pada umumnya nilai embodied energy material dinyatakan dalam MJ/kg, dimana Mega Joule setara dengan $0,948 \mathrm{kBtu}$ (kilo british thermal unit) atau 0,278 $\mathrm{kWh}$ (kilowatt hour). Beberapa nilai koefisien embodied energy material yang banyak digunakan dalam penelitian di bidang embodied energy, antara lain dipublikasikan oleh Inventory of Carbon and Energy (1CE) oleh Hammod dan Jones (2008). Inventaris data energi ini dalam proses awalnya berisi lebih dari 1700 catatan tentang embodied energy yang didapatkan dari 247 sumber data. Inventarisasi data energi yang disediakan oleh University of Bath kemudian mencantumkan hampir 200 material berbeda yang dapat digunakan dalam perhitungan (G. P. Hammond \& Jones, 2008). Data tersebut terus dikembangkan dan diperbarui agar menyesuaikan kondisi industri terbaru (Geoffrey Hammond \& Jones, 2011).

Metode perhitungan embodied energy awal mengacu pada penelitian (Sabaruddin, dkk., 2011) dan pengembangan yang telah dilakukan oleh (Pratiwi, 2011). Tahapan dan metode untuk mengestimasi embodied energy awal pada jenis dinding adalah sebagai berikut:

1. Menentukan jenis konstruksi dinding yang akan dihitung beserta materialnya

Konstruksi dinding terdiri dari material anyaman bambu dan adukan spesi. Material pasangan dinding yang digunakan adalah anyaman/susunan bilik bambu. Sedangkan adukan spesi berfungsi sebagai perekat untuk setiap blok material pasangan dinding, material yang digunakan diantaranya adalah campuran pasir, semen dan air. (Lihat Tabel 2)

Tabel 2. Tabel komponen material pada konstruksi dinding

\begin{tabular}{|l|l|}
\hline Konstruksi Pekerjaan Dinding & \multicolumn{1}{c|}{ Komponen Material } \\
\hline Pasangan Dinding & Anyaman 183amboo \\
\hline Lapisan Dinding & Plaster: PP (Pasir Pasang) dan PC (Portland Cement) dan Acian: PC (Portland Cement) \\
\hline Finishing Dinding & Acian celah spesi: PC (Portland Cement) dan Cat \\
\hline Bukaan Dinding & Kaca (untuk jendela, dan lain-lain) dan Kayu (untuk daun pintu/jendela) \\
\hline
\end{tabular}

Sumber: Analisa Penelitian, 2020

Konstruksi pasangan dinding yang digunakan adalah dinding bambu plester. Untuk membuat $1 \mathrm{~m}^{2}$ dinding anyaman bambu dibutuhkan bahan sebagai berikut (lihat Tabel 3): 
Tabel 3. Indeks material bangunan

\begin{tabular}{|l|l|c|}
\hline \multicolumn{1}{|c|}{ Kebutuhan } & Satuan & Indeks \\
\hline Anyaman bambu & $\mathrm{M}^{2}$ & 0,150 \\
Kayu 5/7 & $\mathrm{M}^{3}$ & 0,014 \\
Paku 4-7 cm & $\mathrm{kg}$ & 0.120 \\
Multiplek & $\mathrm{m}^{2}$ & 0.350 \\
Lem & $\mathrm{kg}$ & 0.640 \\
\hline
\end{tabular}

Sumber : SNI 03-6897-2002 (Standar Nasional Indonesia, 2002)

Konstruksi lapisan dinding yang digunakan antara lain adalah konstruksi plester dan acian. Konstruksi plesteran pada umumnya terdiri dari material semen, pasir dan air, sedangkan acian terdiri dari semen yang dicampur dengan air. Beberapa jenis konstruksi plesteran dan acian yang terdaftar pada SNI 2837:2008 (Standar Nasional Indonesia, 2008a) antara lain adalah:

a. Analisis pekerjaan konstruksi membuat $1 \mathrm{~m}^{2}$ plesteran 1 PC (Portland Cement): 4 PP (Pasir Pasang) tebal $20 \mathrm{~mm}$. Lihat Tabel 4.

Tabel 4. Indeks material bangunan

\begin{tabular}{|l|l|r|}
\hline Kebutuhan & Satuan & Indeks \\
\hline $\mathrm{PC}$ & $\mathrm{kg}$ & 8,320 \\
$\mathrm{PP}$ & $\mathrm{m}^{3}$ & 0,032 \\
\hline
\end{tabular}

Sumber : SNI 2837:2008 (Standar Nasional Indonesia, 2008a)

b. Analisis pekerjaan konstruksi membuat $1 \mathrm{~m}^{2}$ acian. Lihat Tabel 5 .

Tabel 5. Indeks material bangunan

\begin{tabular}{|l|l|l|}
\hline Kebutuhan & Satuan & Indeks \\
\hline PC & $\mathrm{kg}$ & 3,250 \\
\hline
\end{tabular}

Sumber : SNI 2837:2008 (Standar Nasional Indonesia, 2008a)

Beberapa tipe finishing dinding dilakukan dengan finishing skoning pada pasangan dinding menggunakan cat. Untuk susunan komponen bahan pada tipe konstruksi untuk finishing dinding yang terdaftar berdasarkan SNI 2837:2008 (Standar Nasional Indonesia, 2008a) dan SNI 7395:2008 (Standar Nasional Indonesia, 2008c) adalah sebagai berikut:

a. Analisis pekerjaan konstruksi pengecatan $1 \mathrm{~m}^{2}$ tembok eksterior. Lihat Tabel 6.

Tabel 6. Indeks material bangunan

\begin{tabular}{|l|l|l|}
\hline \multicolumn{1}{|c|}{ Kebutuhan } & Satuan & Indeks \\
\hline Plamir/alkali & $\mathrm{kg}$ & 0.085 \\
Cat dasar & $\mathrm{kg}$ & 0,100 \\
Cat penutup 2 kali & $\mathrm{kg}$ & 0.200 \\
\hline
\end{tabular}

Sumber : SNI 2837:2008 (Standar Nasional Indonesia, 2008a)

b. Analisis pekerjaan konstruksi pengecatan $1 \mathrm{~m}^{2}$ tembok interior. Lihat Tabel 7.

Tabel 7. Indeks material bangunan

\begin{tabular}{|l|l|l|}
\hline \multicolumn{1}{|c|}{ Kebutuhan } & Satuan & Indeks \\
\hline Plamir/alkali & $\mathrm{kg}$ & 0.010 \\
Cat dasar & $\mathrm{kg}$ & 0,100 \\
Cat penutup 2 kali & $\mathrm{kg}$ & 0.200 \\
\hline \multicolumn{2}{|c}{. }
\end{tabular}

Sumber : SNI 7395:2008 (Standar Nasional Indonesia, 2008c)

2. Menetapkan nilai dasar embodied energy material $\left(\mathrm{EE}_{\mathrm{m}}\right)$

Untuk mendapatkan nilai EEm, data yang yang didapatkan berdasarkan nilai koefisien embodied energy material berdasarkan ICE (2008), lihat Tabel 8.

Tabel 8. Nilai koefisien embodied energy dari beberapa jenis material bangunan

\begin{tabular}{|l|l|}
\hline Material & Koefisien $\mathbf{( M J} / \mathbf{k g})$ \\
\hline Beton & 1,4 \\
\hline Agregat & 0,11 \\
\hline Semen & 5,08 \\
\hline Bata & 3,0 \\
\hline Conblock/Bata AACB & 3,5 \\
\hline
\end{tabular}




\begin{tabular}{|l|l|}
\hline Material & Koefisien (MJ/kg) \\
\hline Kayu & 8,5 \\
\hline Multiplek & 16 \\
\hline Lem & 12 \\
\hline Kaca & 18,5 \\
\hline Besi/Baja & 35,3 \\
\hline Alumunium & 218,0 \\
\hline Cat & 67,55 \\
\hline
\end{tabular}

Sumber: diadopsi dari Hammond \& Jones (2008) dan Pratiwi (2011)

\section{Menghitung Nilai Embodied Energy Awal Konstruksi (EEAk)}

Nilai $\mathrm{EE}_{\mathrm{m}}$ kemudian dikalikan dengan indeks material berdasarkan jenis pekerjaan dindingnya, sehingga didapatkan nilai embodied energy awal dari setiap tipe pekerjaan dinding (pasangan dinding, lapisan dinding, finishing dinding). Perhitungan ini dilakukan dengan persamaan 1 sebagai berikut:

\section{$\mathrm{EEA}_{\mathrm{k}}=\boldsymbol{\Sigma}\left\{\mathrm{bb}\left(\mathrm{l}_{\mathrm{bb}} \times \mathrm{EE}_{\mathrm{m}}\right)\right\} \mathbf{M J k g}$}

Keterangan:

$\mathrm{EEA}_{k} \quad$ : Embodied energy awal konstruksi

bb : Bahan bangunan

lbb : Indeks bahan bangunan

$\mathrm{EE}_{\mathrm{m}} \quad$ : Nilai dasar embodied energy material bangunan

\section{Menghitung Nilai Embodied Energy Awal Konstruksi (EEAd)}

Setelah didapatkan nilai $\mathrm{EE}_{\mathrm{k}}$ dari setiap jenis pekerjaan dinding, maka selanjutnya hasil tersebut dikalikan dengan masing-masing luas pekerjaannya pada dinding berdasarkan jenis dinding, dan dijumlahkan seluruhnya sehingga didapatkan nilai embodied energy awal dinding $\left(\mathrm{EEA}_{\mathrm{d}}\right)$ dari setiap jenis dinding dengan persamaan 2 berikut:

$\mathrm{EEA}_{\mathrm{d}}=\Sigma \mathrm{Pek}\left(\mathrm{V}_{\mathrm{k}} \times \mathrm{EEA}_{\mathrm{k}}\right) \mathrm{MJ}$

Keterangan:

EEA $\quad$ : Nilai embodied energy awal dinding

Pek : Jenis pekerjaan

$V_{k} \quad$ : Volume konstruksi dinding

EEA $_{k} \quad$ : Analisa embodied energy awal konstruksi dinding

\section{Menghitung Nilai Embodied Energy Awal Konstruksi (EEAT)}

Setelah dilakukan perhitungan terhadap nilai embodied energy awal konstruksi pekerjaan dinding, maka langkah selanjutnya dilakukan perhitungan total embodied energy awal per satuan luas bangunan dengan persamaan 3 berikut:

$$
\text { EEAT }=\Sigma E E A_{d}: L B ~ M J / m^{2}
$$

Keterangan:

EEAT : Total embodied energy awal

EEA $\quad$ : Nilai embodied energy awal dinding

LB : Luas total bangunan

\subsection{Metode Perhitungan Embodied Energy Perawatan Dinding}

Dalam melakukan perhitungan EE untuk perawatan bangunan, faktor-faktor yang mempengaruhi embodied energy berulang ini antara lain adalah usia bangunan (sesuai dengan regulasi yang ada), strategi dan penggunaan material untuk perawatan. Penelitian yang dilakukan Ting (2006), menunjukkan bahwa elemen dinding pada kasus rumah dan komponennya memberikan pengaruh yang signifikan terhadap total embodied energy bangunan. Besar pengaruh elemen dinding tersebut telah dirangkum pada Tabel 4. Dari studi kasus yang dilakukan Ting (2006), urutan jenis konstruksi dinding luar dengan nilai embodied tinggi adalah konstruksi dinding material bata (pada rumah menengah) dan konstruksi dinding material beton precast (pada rumah berlantai banyak), tercantum pada Tabel 9 . 
Tabel 9. Pengaruh konstruksi dinding terhadap total embodied energy

\begin{tabular}{|l|c|c|c|}
\hline \multirow{2}{*}{ Tipe Rumah Berdasarkan Kepadatan Penghuni } & \multicolumn{3}{|c|}{ Pengaruh Terhadap Embodied Energy } \\
\cline { 2 - 4 } & Dinding Eksternal & Dinding Internal & Finishing \\
\hline Single (2 lantai) & $34,7 \%$ & $4,4 \%$ & $5,3 \%$ \\
\hline Menengah (4 lantai) & $32 \%$ & $12,7 \%$ & $6,7 \%$ \\
\hline Tinggi (>12 lantai) & $50,6 \%$ & $1,6 \%$ & $7,8 \%$ \\
\hline
\end{tabular}

Untuk melakukan perhitungan terhadap embodied energy perawatan, hal paling utama adalah strategi pengguna dalam melakukan perawatan terhadap dinding bangunan. Dalam hal ini proses wawancara terhadap pengguna dan arsitek dilakukan untuk memperoleh data strategi perawatan dinding bangunan. Dalam tahap perhitungan ini mengadopsi penelitian oleh (Pratiwi, 2011) dalam menentukan kebutuhan energi dalam perawatan bangunan yang dikembangkan dari (Sabaruddin dkk., 2011). Tahapan dan metode untuk mengestimasi embodied energy perawatan pada jenis dinding adalah sebagai berikut:

1. Menentukan strategi perlakuan terhadap dinding dalam fase perawatan selama beberapa tahun ke depan. Dari hasil yang diperoleh, perawatan bangunan hanya melakukan pengecatan kembali pada permukaan dinding dalam asumsi per tahun usia bangunan.

2. Menentukan besaran indeks koefisien yang dibutuhkan berdasarkan pekerjaan yang dilakukan selama fase perawatan. Indeks mengacu pada SNI 2837:2008 (Standar Nasional Indonesia, 2008a) dan SNI 7395:2008 (Standar Nasional Indonesia, 2008c) untuk pekerjaan cat penutup 1 kali dengan besar indeks adalah 0,100 .

3. Menetapkan nilai dasar embodied energy material $\left(\mathrm{EE}_{\mathrm{m}}\right)$ yang didapatkan berdasarkan nilai koefisien embodied energy material (ICE ,2008), lihat Tabel 2.

4. Menganalisis nilai embodied energy untuk tipe perawatan dinding dengan persamaan 4 berikut:

\section{$\mathrm{EEP}_{\mathrm{k}}=\Sigma\left\{b b\left(\mathrm{l}_{\mathrm{bb}} \times \mathrm{EE}_{\mathrm{m}}\right)\right\} \mathrm{MJkg}$}

Keterangan:

EEP $_{k} \quad:$ Embodied energy perawatan konstruksi dinding

bb : Bahan bangunan

lbb : : Indeks bahan bangunan

Nde $\quad$ : Nilai dasar embodied energy bahan bangunan

5. Setelah diperoleh hasil perhitungan embodied energy perawatan konstruksi dinding, selanjutnya hasil tersebut dikalikan terhadap durasi perawatan dalam tahun. Periode waktu ditentukan selama50 tahun perawatan bangunan. Durasi ini sesuai dengan Peraturan Menteri Pekerjaan Umum Republik Indonesia Nomor 45 Tahun 2007. Nilai EE dapat dihitung dengan persamaan 5 sebagai berikut:

\section{$\operatorname{EEP}_{d}=\Sigma P_{e k}\left(V_{k} \times E_{E} P_{k} \times t\right) M J$}

Keterangan:

$\begin{array}{ll}\mathrm{EEP}_{\mathrm{d}} & : \text { Nilai } \text { embodied energy perawatan komponen dinding } \\ \mathrm{Pek} & : \text { Jenis pekerjaan } \\ \mathrm{V}_{\mathrm{k}} & : \text { Volume konstruksi dinding } \\ \mathrm{EEP}_{\mathrm{k}} & : \text { Analisa } \text { embodied energy perawatan konstruksi dinding } \\ \mathrm{t} & : \text { Durasi perawatan }\end{array}$

6. Melakukan perhitungan besar embodied energy per satuan luas bangunan. Perhitungan pada persamaan 6 ini dilakukan untuk mempermudah perbandingan penggunaan embodied energy perawatan persatuan volume yang ditentukan.

$\mathrm{EEPT}=\boldsymbol{\Sigma} E E P_{\mathrm{d}}: \mathrm{LB} \mathrm{MJ} / \mathrm{m}^{2}$

Keterangan:

EEPT : Total embodied energy perawatan 
EEP $_{d} \quad$ : Nilai embodied energy perawatan dinding

LB : Luas total bangunan

\subsection{Metode Perhitungan Embodied Energy Total Dinding}

Untuk mendapatkan total embodied energy dinding, tercantum pada persamaan 7 sebagai berikut:

$$
E E T \text { = EEAT + EEPT MJ/m² }
$$

Keterangan:

EET : Total embodied energy konstruksi dinding

EEAT : Total embodied energy awal dinding

EEPT : Total embodied energy perawatan dinding

\section{Hasil dan Pembahasan}

\subsection{Hasil Perhitungan Embodied Energy Awal}

Perhitungan yang dilakukan terhadap embodied energy awal bangunan melalui tiga fase perhitungan, yaitu: (1) perhitungan nilai embodied energy pada pekerjaan awal dengan menghitung indeks bahan bangunan dan nilai dasar embodied energy, (2) perhitungan nilai embodied energy awal dinding bangunan berdasarkan luas permukaan konstruksi dan (3) penentuan nilai embodied energy awal per meter persegi.

Pada Tabel 10, disajikan hasil perhitungan dari nilai embodied energy pada pekerjaan awal atau biasanya disebut dengan nilai intensitas energi pekerjaan. Sesuai dengan SNI, jenis pekerjaannya antara lain pasangan dinding, plesteran, acian, serta finishing dalam dan luar. Nilai ini kemudian dikalikan dengan luas bidang pekerjaan untuk mendapatkan nilai total embodied energy awal.

Tabel 10. Hasil perhitungan nilai embodied energy pada pekerjaan awal

\begin{tabular}{|c|c|c|c|c|c|}
\hline No & $\mathbf{E E A}_{\mathbf{k}}$ & Bahan & Indeks & $\mathbf{E E}_{\mathbf{m}}$ & Total \\
\hline \multirow[t]{5}{*}{1} & \multirow[t]{5}{*}{ Pasangan Konstruksi Dinding } & Anyaman bambu & 0,150 & 8.50 & 1,275 \\
\hline & & Kayu 5/7 & 0,014 & 8,50 & 0,119 \\
\hline & & Paku $4-7 \mathrm{~cm}$ & 0,120 & 35,30 & 4,236 \\
\hline & & Multiplek & 0,350 & 16,00 & 5,600 \\
\hline & & Lem kuning & 0,640 & 12,00 & 7,680 \\
\hline \multirow{3}{*}{2} & & & & & 18,910 \\
\hline & \multirow[t]{2}{*}{ Lapisan Dinding (Plesteran) } & $\mathrm{PC}$ & 8,320 & 5.08 & 42,266 \\
\hline & & PP & 0,032 & 5,08 & 0,163 \\
\hline \multirow{3}{*}{3} & & & & & 42,429 \\
\hline & Lapisan Dinding (Acian) & $\mathrm{PC}$ & 3,250 & 5,08 & 16,510 \\
\hline & & & & & 16,510 \\
\hline \multirow[t]{3}{*}{4} & \multirow[t]{3}{*}{ Finishing Dinding (Luar) } & Plamir/alkali & 0.085 & 67,55 & 5,741 \\
\hline & & Cat dasar & 0,100 & 67,55 & 6,755 \\
\hline & & Cat penutup 2 kali & 0.200 & 67,55 & 13,510 \\
\hline \multirow{4}{*}{5} & & & & & 26,006 \\
\hline & \multirow[t]{3}{*}{ Finishing Dinding (Dalam) } & Plamir/alkali & 0.010 & 67,55 & 0,676 \\
\hline & & Cat dasar & 0,100 & 67,55 & 6,755 \\
\hline & & Cat penutup 2 kali & 0.200 & 67,55 & 13,510 \\
\hline & & & & & 20,941 \\
\hline
\end{tabular}

Sumber: Analisa Penelitian, 2020

Perhitungan selanjutnya disajikan dalam Tabel 11 secara lengkap. Dari hasil perhitungan dalam Tabel 11 tersebut telah diperoleh nilai 3.889,819 MJ sebagai nilai total embodied energy dari sampel bangunan dinding bambu plester dengan luas $16 \mathrm{~m}^{2}$.

Tabel 11. Hasil perhitungan nilai embodied energy dinding

\begin{tabular}{|c|l|r|r|r|}
\hline No & \multicolumn{1}{|c|}{ EEA $_{\mathbf{d}}$} & $\mathbf{E E A}_{\mathbf{k}}$ & \multicolumn{1}{|c|}{ Volume $\left.\mathbf{( m}^{\mathbf{2}}\right)$} & Total \\
\hline $\mathbf{1}$ & Pasangan Dinding & $\mathbf{1 8 , 9 1 0}$ & $\begin{array}{r}\text { 64-((0.6x3)+(0.81 x 2)+2) } \\
=60,2\end{array}$ & $1.138,382$ \\
& & & $32-0.81=31.19$ & 1323,361 \\
\hline $\mathbf{2}$ & Lapisan Dinding (Plesteran) & $\mathbf{4 2 , 4 2 9}$ & $32-0.81=31.19$ & 514,947 \\
\hline $\mathbf{3}$ & Lapisan Dinding (Acian) & $\mathbf{1 6 , 5 1 0}$ & $16-0.81=15.19$ & 395,031 \\
\hline $\mathbf{4}$ & Finishing Dinding (Luar) & $\mathbf{2 6 , 0 0 6}$ & $16-0.81=15.19$ & 318,098 \\
\hline $\mathbf{5}$ & Finishing Dinding (Dalam) & $\mathbf{2 0 , 9 4 1}$ & & \\
\hline
\end{tabular}


Sumber: Analisa Penelitian, 2020

Selanjutnya dalam perhitungan nilai tersebut dibagi dengan luas total bangunan. Total embodied energy dinding bambu plester di bangunan wisata Kampung Buyut Cipageran per meter persegi adalah $231 \mathrm{MJ} / \mathrm{m}^{2}$. Apabila mengacu pada Australia's Guide to Environmentally Sustainable Homes bahwa untuk dinding bata konvensional memiliki standar EEAT $440 \mathrm{MJ} / \mathrm{m}^{2}$. Nilai ini hampir dua kali lipat dari nilai EEAT dinding bambu plester yang diperoleh dari perhitungan dalam penelitian ini.

\subsection{Hasil Perhitungan Embodied Energy Perawatan}

Perhitungan yang dilakukan terhadap embodied energy perawatan bangunan melalui tiga fase perhitungan, yaitu: (1) perhitungan nilai embodied energy pada pekerjaan awal dengan menghitung indeks bahan bangunan dan nilai dasar embodied energy, (2) perhitungan nilai embodied energy awal dinding bangunan berdasarkan luas permukaan konstruksi dan durasi perawatan bangunan dan (3) penentuan nilai embodied energy awal per meter persegi. Tabel 12 dan 13 merupakan perhitungan EEPT.

Tabel 12. Hasil perhitungan nilai embodied energy per material perawatan dinding

\begin{tabular}{|c|c|c|c|c|c|}
\hline No & $\mathbf{E E P}_{k}$ & Bahan & Indeks & EEm & Total \\
\hline $\mathbf{1}$ & Finishing Dinding (Luar) & Cat penutup & 0.100 & 67,55 & 6,755 \\
\hline & & & & & 6,755 \\
\hline 2 & Finishing Dinding (Dalam) & Cat penutup & 0.100 & 67,55 & 6,755 \\
\hline & & & & & 6,755 \\
\hline
\end{tabular}

Sumber: Analisa Penelitian, 2020

Setelah dilakukan perhitungan terhadap EEPd, diperoleh nilai 205,22 MJ. Nilai ini merupakan hasil perkalian antara nilai EEPk per masing-masing pekerjaan dengan jumlah total volume pekerjaan. (Lihat Tabel 13)

Tabel 13. Hasil perhitungan nilai embodied energy perawatan dinding

\begin{tabular}{|l|l|l|r|r|}
\hline No & \multicolumn{1}{|c|}{ EEP $_{\mathbf{d}}$} & EEPk & Volume (m2) & Total \\
\hline $\mathbf{1}$ & Finishing Dinding (Luar) & $\mathbf{6 , 7 5 5}$ & $16-0.81=15.19$ & 102,608 \\
\hline $\mathbf{2}$ & Finishing Dinding (Dalam) & $\mathbf{6 , 7 5 5}$ & $16-0.81=15.19$ & 102,608 \\
\hline \multicolumn{3}{|l|}{} & $\mathbf{2 0 5 , 2 2}$ \\
\hline
\end{tabular}

Sumber: Analisa Penelitian, 2020

Berdasarkan Peraturan Menteri Pekerjaan Umum Nomor 45 Tahun 2007, umur bangunan diperhitungkan selama 50 tahun. Oleh karena itu, perhitungan $\mathrm{EEP}_{\mathrm{d}}$ bangunan dilakukan selama 50 tahun, sehingga diperoleh nilai 10.260 MJ. Selanjutnya nilai EEPT ditentukan dengan membagi hasil tersebut dengan luas bangunan $\left(16 \mathrm{~m}^{2}\right)$ dan diperoleh $641 \mathrm{MJ} / \mathrm{m}^{2}$.

Untuk membandingkan EEPT cenderung sulit dilakukan karena biasanya beberapa penelitian sebelumnya menggunakan standar 30 tahun, 40 tahun (A. Utama \& Gheewala, 2009) hingga 50 tahun dari umur bangunan (Huang, dkk, 2017) dengan asumsi batasan yang berbeda-beda.

\subsection{Hasil Perhitungan Embodied Energy Total}

Hasil perhitungan EEA dan EEP kemudian dijumlahkan untuk mengetahui EET, yaitu $231 \mathrm{MJ} / \mathrm{m}^{2}+$ $641 \mathrm{MJ} / \mathrm{m}^{2}=872 \mathrm{MJ} / \mathrm{m}^{2}$. Nilai EEP selama 50 tahun membutuhkan hampir tiga kali lipat dari nilai EEA.

\subsection{Pembahasan}

Bambu dikenal sebagai tanaman yang dapat tumbuh di berbagai kondisi iklim dan dapat diproduksi dalam waktu yang cukup singkat. Selain itu, bambu sendiri memiliki karakteristik tersendiri jika dibandingkan dengan material lain yang biasa digunakan untuk bangunan. Material bambu sudah digunakan sejak dahulu untuk komponen bangunan khususnya dinding. Saat ini masih dapat ditemukan bangunan dengan dinding bambu atau anyaman bambu di beberapa daerah di Indonesia. Penggunaan material ini memang mulai ditinggal oleh masyarakat sejak adanya bata sebagai bahan bangunan yang lebih solid dan rigid.

Penggunaan bambu sebagai bahan dasar material dinding kemudian dilakukan pengembangan dengan menambahkan perlakuan tertentu terhadap material tersebut kemudian ditambahkan plester seperti dinding bata pada umumnya. Perlakuan ini tentu membuat dinding bambu lebih solid dan rigid dan hampir menyamai fungsi dinding batu bata. Penggunaan model dinding seperti ini digunakan dalam proyek rumah singgah di Kampung Buyut Cipageran, Kota Cimahi. 
Dalam melakukan metode perhitungan embodied energy, diperlukan data-data awal seperti kandungan embodied energy per satuan material, indeks pekerjaan konstruksi, dan strategi perawatan. Beberapa data ini diperoleh dari ICE yang dipublikasikan oleh University of Bath, SNI dan hasil wawancara dengan pengguna/arsitek. Data yang berasal dari ICE cukup diakui pada beberapa penelitian embodied energy. Meskipun begitu, sebagian besar data ini diambil pada aktivitas industri di United Kingdom dan Eropa. Dapat diasumsikan bahwa terdapat perbedaan nilai energi sebenarnya dari aktivitas industri di Indonesia dimana studi kasus dibahas. Di dalam data tersebut, data untuk embodied energy dasar material bambu sendiri belum ada dalam ICE, namun penggunaan material bambu yang bersifat lokal dapat diasumsikan sama dengan penggunaan kayu sebagai material bahan bangunan. Material lokal merupakan material yang dapat diperoleh dalam radius kurang lebih $50 \mathrm{~km}$.

Dari perhitungan-perhitungan yang telah dilakukan, diperoleh beberapa data EE yang terkandung dalam dinding bambu plester pada bangunan di Kampung Buyut Cipageran. Nilai EEAT adalah $231 \mathrm{MJ} / \mathrm{m}^{2}$ dan Nilai EEAPT adalah $641 \mathrm{MJ} / \mathrm{m}^{2}$. Berdasarkan beberapa kajian yang dilakukan oleh beberapa instansi dan lembaga bangunan hijau menunjukkan bahwa nilai EEAT merupakan nilai yang dijadikan standar dalam perhitungan embodied energy karena perhitungannya dalam satuan meter persegi. Mengacu pada Australia's Guide to Environmentally Sustainable Homes bahwa untuk dinding bata konvensional memiliki standar EEAT 440 $\mathrm{MJ} / \mathrm{m}^{2}$. Nilai ini hampir dua kali lipat lebih besar dibandingkan penggunaan material bambu sebagai bahan dasar dinding plester. Pada referensi penelitian lain, penggunaan dinding bata tanah liat dapat mencapai 791 $\mathrm{MJ} / \mathrm{m}^{2}$ (Hashemi, Cruickshank, \& Cheshmehzangi, 2015). Penelitian tersebut juga menggunakan data ICE yang terbaru dari Hammond \& Jones (2011). Perbandingan yang dilakukan memang belum 100\% akurat dikarenakan strategi pemenuhan kebutuhan material dari pembuatan, transportasi dan operasional yang berbeda di hampir setiap negara. Penilaian yang dilakukan sudah cukup membuktikan bahwa dinding bambu plester membutuhkan energi yang lebih sedikit jika dibandingkan dengan dinding bata konvensional. Dengan isu penggunaan energi yang semakin meningkat, khususnya dalam sektor bangunan, maka penggunaan dinding bambu plester dapat menjadi solusi dalam menjawab isu tersebut.

Dari hasil penelitian, dapat diketahui potensi yang dapat dikembangkan oleh dinding bambu plester ini untuk meminimalisir konsumsi energi pada dinding bangunan. Bukan hanya dalam rangka penurunan energi, dinding bambu juga dapat menghemat biaya sebesar $31,17 \%$ berdasarkan penelitian yang dilakukan oleh Marzuki (2019). Bisa jadi dimasa depan, dinding bambu ini juga dapat dikembangkan secara prefabrikasi seperti yang telah disebutkan oleh Suriani (2017). Meskipun begitu, harus diakui bahwa perlu adanya penelitian yang lebih mendalam yang dapat menghubungkannya dengan unsur lain seperti ketahanan terhadap cuaca, termal dan lain-lain seperti yang dilakukan oleh (Utama, 2006). Terlepas dari hal diatas, penggunaan dinding bambu dapat dikembangkan lebih masif dan terkontrol juga sejalan dengan semangat menjaga dan melestarikan alam seperti semangat dari Kampung Buyut Cipageran.

\section{Kesimpulan}

Bangunan dengan dinding bambu, baik ayaman dan plester, memiliki nilai embodied energy awal sebesar $261 \mathrm{MJ} / \mathrm{m} 2$ dan nilai embodied energy perawatan selama 50 tahun sebesar $641 \mathrm{MJ} / \mathrm{m} 2$. Nilai embodied energy awal lebih rendah dibandingkan embodied energy dinding bata konvensional dengan nilai $440 \mathrm{MJ} / \mathrm{m} 2$. Dinding bambu dapat menjadi solusi untuk masalah penggunaan energi yang besar pada sektor bangunan dan meningkat setiap tahunnya.

\section{Ucapan Terima Kasih}

Terima kasih untuk Bapak Ir. Pon. S. Purajatnika, IAI dari PT. Awi Agraprana Bestari sebagai arsitek pelaksana pekerjaan atas data-data yang telah diberikan.

\section{Referensi}

Ampofo-Anti, N. (2010). Material selection and embodied energy 1. Green Building Handbook South Africa: The Essential Guide, Alive2green, 3, 1-10.

Anonym. (2014). Methodology to the CO2 Calculations: Embodied Energy of Single Material Type. Sustainable Geosystem in Civil Engineering Application.

Dixit, M. K, Fernandez-Solis, J. L., Lavy, S., \& Culp, C. H. (2010). Protocol for Embodied Energy Measurement Parameters. Retrieved

from http://immobilierdurable.eu/images/2128_uploads/__Dixit.pdf

Dixit, Manish K. (2017). Life cycle embodied energy analysis of residential buildings: A review of literature to investigate embodied energy parameters. Renewable and Sustainable Energy Reviews, 79, 390-413. 
https://doi.org/10.1016/J.RSER.2017.05.051

Dixit, Manish K. (2019). Life cycle recurrent embodied energy calculation of buildings: A review. Journal of Cleaner Production, 209, 731-754. https://doi.org/10.1016/j.jclepro.2018.10.230

Ferdelina, Hena S. (2016). Laporan Praktik Industri Proyek Kampung Buyut Cipageran. UPI: Laporan Praktik Industri.

Hammond, G. P., \& Jones, C. I. (2008). Embodied energy and carbon in construction materials. Proceedings of the Institution of Civil Engineers - Energy, 161(2), 87-98. https://doi.org/10.1680/ener.2008.161.2.87

Hammond, Geoff, \& Jones, C. (2008). Inventory of Carbon \& Energy (ICE) Version 1.6a. United Kingdom. Retrieved from www.bath.ac.uk/mech-eng/sert/embodied/

Hammond, Geoffrey, \& Jones, C. (2011). A BSRIA guide: Embodied Carbon: The Inventory of Carbon and Energy (ICE). (F. Lowrie \& P. Tse, Eds.). United Kingdom: BSRIA BG \& University of Bath. Retrieved from www.bath.ac.uk/mech-eng/sert/embodied/

Hanifah, Y., Reztrie, N. D., Ramadhan, T., \& Larasati, D. (2019). Evaluation of Material Selection on the Initial Embodied Energy Value of Low-Middle Apartment in Indonesia. In SBE_Tokyo (Ed.), IOP Conf. Series: Earth and Environmental Science (Vol. 294). Tokyo: IOP Publishing. https://doi.org/10.1088/1755-1315/294/1/012036

Hashemi, A., Cruickshank, H., \& Cheshmehzangi, A. (2015). Environmental Impacts and Embodied Energy of Construction Methods and Materials in Low-Income Tropical Housing. Sustainability, 7(June), 78667883. https://doi.org/10.3390/su7067866

Huang, L., Liu, Y., Krigsvoll, G., \& Johansen, F. (2017). Life cycle assessment and life cycle cost of university dormitories in the southeast China: Case study of the university town of Fuzhou. Journal of Cleaner Production, 1-9. https://doi.org/10.1016/j.jclepro.2017.06.021

Ibn-Mohammed, T., Greenough, R., Taylor, S., Ozawa-Meida, L., \& Acquaye, A. (2013). Operational vs. embodied emissions in buildings - A review of current trends. Energy and Buildings, 66, 232-245. https://doi.org/10.1016/j.enbuild.2013.07.026

Kementerian Pekerjaan Umum dan Perumahan Rakyat. (2007). Peraturan Menteri Pekerjaan Umum Nomor: 45/PRT/M/2007 Tentang Pedoman Teknis Pembangunan Bangunan Gedung Negara.

Larasati, D., Wahyuni, Y. S., Suhendri, \& Triyadi, S. (2017). Embodied Energy Calculation in Mitigating Environmental Impact of Low-Cost Housing Construction. In EDP Sciences (Ed.), MATEC Web of Conferences (Vol. 138). EDP Sciences. https://doi.org/10.1051/matecconf/201713801001

Marzuki, I. (2019). Analisis Penggunaan Bambu Plester Terhadap Penurunan Biaya. Jurnal Ilmiah Techno Entrepreneur Acta, 4(December), 117-123.

Nairobi (1991). Energy for Building - Improving Energy Efficiency in Construction and in the Production of Building Materials in Developing Countries. Journal United Nations Centre for Human Settlements (Habitat).

Pratiwi, Sri N. (2014). Kajian Embodied Energy Dinding Pada Berbagai Tipe Rumah Susun. ITB: Tesis.

Ramesh, T., Prakash, R., \& Shukla, K. K. (2010). Life cycle energy analysis of buildings: An overview. Energy and Buildings, 42(10), 1592-1600. https://doi.org/10.1016/j.enbuild.2010.05.007

Sabaruddin, A., Karyono, T. H., \& Tobing, R. (2011). Model Perhitungan Kandungan Emisi CO2 Pada Bangunan Gedung. CO2 Emission Greenhouse Gas Effect and Global Warming Building Energy.

Sentzas, K., Tsiamitros, D., Stephanedes, Y. J., \& Cities, S. (2017). A hybrid life cycle analysis method for the environmental assessment of conventional building materials. In 6th International Conference "ENERGY in BUILDINGS 2017. Athens, Hellas: ASHRAE Hellenic Chapter.

Standar Nasional Indonesia. (2002). SNI 03-6897-2002 Tata cara perhitungan harga satuan pekerjaan pasangan dinding. (Badan Standardisasi Nasional, Ed.). Badan Standardisasi Nasional.

Standar Nasional Indonesia. (2008a). SNI 2837:2008 Tata cara perhitungan harga satuan pekerjaan plesteran untuk konstruksi bangunan gedung dan perumahan. (Badan Standardisasi Nasional, Ed.). Indonesia: Badan Standardisasi Nasional.

Standar Nasional Indonesia. (2008b). SNI 6897:2008 Tata cara perhitungan harga satuan pekerjaan dinding untuk konstruksi bangunan gedung dan perumahan. (Badan Standardisasi Nasional, Ed.). Badan Standardisasi Nasional.

Standar Nasional Indonesia. (2008c). SNI 7395:2008 Tata cara perhitungan harga satuan pekerjaan penutup lantai dan dinding untuk konstruksi bangunan gedung dan perumahan. (Badan Standardisasi Nasional, Ed.). Badan Standardisasi Nasional.

Surahman, U., Kubota, T., \& Higashi, O. (2015). Life Cycle Assessment of Energy and CO2 Emissions for Residential Buildings in Jakarta and Bandung, Indonesia. Buildings, 5(4), 1131-1155. 
https://doi.org/10.3390/buildings5041131

Suriani, E. (2017). Bambu Sebagai Alternatif Penerapan Material Ekologis: Potensi dan Tantangannya. EMARA Indonesian Journal of Architecture, 3(1), 33-42.

Ting, S. K. (2006). Optimisation of Embodied Energy in Domestic Construction. RMIT University. https://doi.org/10.2749/222137804796302671

Treloar, G. J. (1998). A Comprehensive Embodied Energy Analysis Framework. Faculty of Science and Technology, Deakin University.

Utama, A., \& Gheewala, S. H. (2009). Indonesian residential highrise buildings: A life cycle energy assessment. Energy and Buildings, 41(11), 1263-1268. https://doi.org/10.1016/j.enbuild.2009.07.025

Utama, N. A. (2006). Embodied Energy of Building Envelopes and its Influence on Cooling Load in Typical Indonesian MiddleClass Houses. In The 2nd Joint International Conference on "Sustainable Energy and Environment (SEE 2006) (pp. 1-5). Bangkok, Thailand.

Utama N. A, dkk., (2008): Life Cycle Energy of Single Landed Houses in Indonesia, Energy And Buildings. Journal Energy Buildings, 40, 1911-1916.

Wahyuni, Y. S., \& Larasati, D. (2017). Identifikasi Nilai Embodied Energy sebagai Upaya Mitigasi Energi dalam perencanaan Bangunan. Jurnal Lingkungan Binaan Indonesia, 6(50), 9-15.

Waqas, A., \& Ud Din, Z. (2013). Phase change material (PCM) storage for free cooling of buildings - A review. Renewable and Sustainable Energy Reviews. Elsevier. https://doi.org/10.1016/j.rser.2012.10.034

Zhang, X., \& Wang, F. (2016). Assessment of embodied carbon emissions for building construction in China: Comparative case studies using alternative methods. Energy and Buildings, 130, 330-340. https://doi.org/10.1016/j.enbuild.2016.08.080 